\title{
Parting editorial: Renewing Earth and its people - translating science into practice
}

With some regret I announce my retirement as Editor-inChief. Over the past decade, Renewable Agriculture and Food Systems (RAFS) has broadened the original scope of its predecessor, American Journal of Alternative Agriculture. We strongly encourage publication of practical and integrated, biologically based systems approaches that meet the challenges of social and economic change, dwindling natural resources and climatic instability in achieving the global vision of 'Renewing Earth and its people' with a focus on 'Translating science into practice'.

Renewable Agriculture and Food Systems stands apart from other journals in its field. Its unique nature, recently tabulated by a polling of Associate Editors and practitioners around the world, include the following:

International breadth: with increasing numbers of contributions from three global regions: Asia/Australasia, Eastern Europe/Middle East/Africa and North/Central/ South America.

Emphasis: a focus on biologically based integrated systems approaches, including rural/urban agricultural sociology, and focus on food systems issues.

Multiple content categories: including original peerreviewed Research papers and Review articles, Preliminary reports, Forum, Commentaries, and Book reviews. The journal occasionally publishes themed issues.

Efficient review process: leading generally to decisions on manuscripts within 2-3 months after submission and online publication 4-6 weeks after acceptance.

Promotion of participatory interactions: with practitioners through coverage of a wide range of topics of interest to them, using less technical jargon, and providing practical, workable applications and solutions aimed at increasing sustainability.

Themed issues: often co-edited by Associate Editors, focus on specific topics to broaden understanding beyond contemporary agriculture to include renewable agricultural systems that contribute to a sustainable future. Examples include: Perennial grain crops (Volume 20 Issue 1); Soil quality for sustainable management (Volume 21 Issue 1); Meeting food and resource needs: Organic agriculture and the global food supply (Volume 22 Issue 2); Researching sustainable agricultural systems, ISOFAR 2005 (Volume 23 Issue 1); Principles of integrated agricultural systems (Volume 23 Issue 4); Food for life: Looking beyond the horizon (Volume 25 Issue 1); Sustainable agricultural systems in a resource limited future (Volume 25 Issue 2).

In 2012 (Volume 27), a themed issue on Conservation tillage strategies in organic management systems will highlight the differences in degree and nature of reduced tillage in organic management systems between Europe and North America due to differences in climate, soils, economic, social and cultural issues.

Forum: this provides a discussion section for researchers, farmers and others, to encourage focused dialog, on often controversial topics, with widely divergent viewpoints. The most controversial and widely visited Forum discussion was 'Can organic agriculture feed the world?' by Badgley and Perfecto ${ }^{1}$ which included detailed criticisms from a renowned scientist and a progressive Great Plains farmer. A scathing Commentary on. "Organic abundance" report: Fatally flawed' by Alex Avery ${ }^{2}$ and Responses to it were published two issues later in December 2007.

Preliminary reports on highly innovative systems: these cover areas about which little prior research has been done but which show promise for development into highly valuable and exciting renewable management systems. One example, a report on floating gardens in Bangladesh by Irfanullah et al. ${ }^{3}$, used water hyacinth weeds that were hazards to navigation in river channels to build floating gardens in bordering wetlands - thus helping to remediate problems of nutritional security and lack of arable land accessibility in coastal villages where rising sea levels threaten human activities and livelihoods.

I would like to extend thanks to our outstanding and dedicated group of Associate Editors and the many reviewers who provided timely, substantive and insightful reviews over the past decade. Your efforts have resulted in a quality journal with timely publication. A special recognition is given to Valerie Dennis, our 'miracle worker' editorial office manager, whose efforts have greatly facilitated the timely review of manuscripts and provided needed guidance and relief from intermittent frustrations with 'electronic' editing. Gratitude is also extended to the journal support staff of the Henry Wallace Institute of Alternative Agriculture, CABI and, most recently, Cambridge University Press for outstanding support in publishing the journal. One indication of the journal's advancement is the almost tripling of the Impact Factor between 2005 and 2009. A special thanks to three Associate Editors who are retiring with me at the end of 2011: Molly Anderson, College of the Atlantic, Maine USA, for her 20 years of service as an Associate Editor and contributions to sustainable food systems; Mark Liebig, USDA-ARS Soil Scientist at the Northern Great Plains Research Center, for his inspiration to me as my 'professional' son and his 9 years' service as an Associate and Forum Editor; and last but not least to John Ryan, internationally renowned dryland soil specialist, ICARDA/CGIAR, Syria for his 9 years' service as an 
Associate Editor and his patience in listening to outlandish visions from this fellow Irishman.

I recognize the pioneering efforts of former Editors:

Garth Youngberg, a visionary before his time, for founding and defining the vision of American Journal of Alternative Agriculture and in blazing a trail through the forest of political, social and professional opposition to the notion that the continued adoption of agricultural technologies relying heavily on fossil fuel energy, capital and chemical inputs was not environmentally or economically sustainable.

Dr William Lockeretz, for his commitment and role as Editor and Technical Editor, over a 12-year period, which documented the history and helped promote the viability of organic agriculture as a sustainable alternative to chemically intensive industrial agriculture (see Volume 23 themed issue 1, Researching sustainable agricultural systems, ISOFAR 2005; and the Volume 25 Issue 1, Book review of Organic Farming ${ }^{4}$ ).

Dr Robert Papendick, Soil Scientist, Pullman, Washington for his 5 years service as Editor of American Journal of Alternative Agriculture and his contributions to maintaining the credibility and high caliber of the journal and in emphasizing the importance of the quality of soil resources in maintaining sustainable food production and food and environmental health.

A special recognition to Charles 'lightning' Francis who has served as an Associate Editor from the beginning, recently serving as Resources Review Editor and in essence as a Co-Editor-in-Chief through numerous consultations, Commentaries, Editorials, and for his amazing capacity to digest and succinctly summarize large amounts of information in a short period of time.

I hope that this editorial has done justice to those that came before me in my quarter century of service to the journal. The journal name and cover were changed in 2004 because the journal had emerged to the point where the systems it was promoting were no longer merely 'alternatives' to conventional agriculture, but solutions to sustainability. The journal continues to provide a common ground where scientists, educators, policy makers, environmentalists, farmers, community organizers and other practitioners of various perspectives can share their research and ideas for affirming Renewable agriculture and food systems that meet people's needs and restore the productive capacity of the Earth. In my tenure as Editor-in-Chief, and my career as a scientist, my personal goal has been to 'translate science into practice' by creating tools and approaches for building soil health and renewing an agriculture/social system that would help us flourish in this new millennium through re-forging partnerships with all of society and the natural world that supports us. My vision for practical science and foundation for scientific concepts was nurtured by several 'people of the land' such as George Tasker, my father-inlaw, timberman and self-educated ecologist from the Appalachian Mountains of Virginia; farmers and futurists
Dick and Sharon Thompson, Fred Kirschenmann and Wes Jackson from America's heartland; and John Jeavons for his development of Grow Biointensive Agriculture ${ }^{5}$ that is meeting basic soil, food and people's needs in over 100 countries and urban sites around the world.

A special thanks to my wife and life partner, Janet, who kept the home fires burning and cared for our daughter Karin while I traveled the world, in co-founding with me the Renewing Earth and Its People Fund (www.reapfund. org) and for patiently serving as my first Editorial Assistant for the journal.

I welcome the new Editor-in-Chief Rick Welsh, Professor of Sociology, Clarkson University, NY, USA and his assistant Lydia Oberholtzer, a Senior Researcher with Pennsylvania State University. They not only bring a new sociological strength to the journal but also maintain our historical connection with the Henry A. Wallace Center for Agricultural and Environmental Policy at Winrock International. Rick and Lydia have met with Cambridge University Press to discuss future plans for changes needed to maintain the scientific excellence and practical significance of Renewable Agriculture and Food Systems. Seeking to support the global expansion of the journal, the new Editors and Cambridge University Press will explore ways to assist authors from developing and other countries, for which English is not their primary language, to submit reports on unique and innovative food production systems for consideration of publication in the journal.

\section{References}

1 Badgley, C. and Perfecto, I. 2007. Can organic agriculture feed the world? Renewable Agriculture and Food Systems 22:80-86.

2 Avery, A. 2008. 'Organic abundance' report: fatally flawed. Renewable Agriculture and Food Systems 22:321-323.

3 Irfanullah, H.Md., Adrika, A., Ghani, A., Khan, Z.A., and Rashid, Md.A. 2008. Introduction of floating gardening in the north-eastern wetlands of Bangladesh for nutritional security and sustainable livelihood. Renewable Agriculture and Food Systems 23:89-96.

4 Francis, C. 2010. Organic Farming: An International History. Edited by William Lockeretz. Renewable Agriculture and Food Systems 25:81-82.

5 Doran, J.W. 2000. Additional soil quality building options. In H. Roberts (ed.). Proceedings from the 'Soil, Food, and People Conference: A Biointensive Model for the Next Century', Ecology Action, CA, USA. p. 90-94.

John Walsh Doran

Editor-in-Chief, Renewable Agriculture and Food Systems

Co-Founder, Renewing Earth and Its People (www.reapfund.org)

Professor and Scientist Emeritus, University of Nebraska and USDA-ARS, Lincoln, NE, USA. doranrafs@gmail.com 